\title{
Alevi Cultural Heritage in Turkey and Germany: Negotiating "Useable Pasts" in Transnational Space
}

Benjamin Weineck

\section{(2) OpenEdition \\ Journals}

Electronic version

URL: http://journals.openedition.org/ejts/5206

DOI: $10.4000 /$ ejts.5206

ISSN: $1773-0546$

Publisher

EJTS

Electronic reference

Benjamin Weineck, " Alevi Cultural Heritage in Turkey and Germany: Negotiating "Useable Pasts" in Transnational Space », European Journal of Turkish Studies [Online], 20 | 2015, Online since 10 April 2015, connection on 16 February 2020. URL : http://journals.openedition.org/ejts/5206 ; DOI : $10.4000 /$ ejts.5206

This text was automatically generated on 16 February 2020.

(C) Some rights reserved / Creative Commons license 


\title{
Alevi Cultural Heritage in Turkey and Germany: Negotiating "Useable Pasts" in Transnational Space
}

\author{
Benjamin Weineck
}

\section{Introduction}

1 Since the beginning of the millennium a number of activities have been carried out by UNESCO to promote the safeguarding of the Intangible Cultural Heritage of Humanity. The Convention for the Safeguarding of Intangible Cultural Heritage in 2003 was followed by the Convention on the Protection and Promotion of the Diversity of Cultural Expression (2005) to maintain and "enrich cultural diversity", with Intangible Cultural Heritage considered to be the "mainspring" of cultural pluralism (UNESCO Convention 2003: §3).

In 2010 a committee consisting of members elected by state parties of UNESCO's General Assembly decided to include the ritual dance semah, a sequence of the AleviBektaşi $^{1}{ }^{1}$ cem ritual ${ }^{2}$, on the Representative List of Intangible Cultural Heritage. Alevi-Bektaşi heritage was subsequently listed on Turkey's National Inventory of Cultural Heritage, "fostering and enriching [the] traditional music culture of Turkey" (UNESCO Nomination file 2010: 6).

3 The latter aspect of its inscription on Turkey's inventory list is particularly remarkable. Alevi history in the Republic of Turkey as well as in the Ottoman Empire has often been perceived by many Alevis as constituting a "history of suppression" (Göner 2005: 111) with ongoing issues of institutional, cultural, and social marginalization. Recognition of the contribution of an Alevi ritual to the enrichment of Turkey's cultural diversity would thus seem to challenge the nation's dominant Sunni-Turkist conception of belonging. Furthermore, it would also appear to support UNESCO's objective of empowering vernacular groups by safeguarding their creative cultural practices as Intangible Cultural Heritage, ICH. Three years after the categorization of the semah ritual as Cultural Heritage in Turkey, members of the Alevi community in Germany, 
Almanya Alevi Birlikleri Federasyonu, AABF, raised the possibility of inscripting the semah ritual onto the Representative List via a federal UNESCO bureau. Prohibition of the performance of the ritual in Turkey was given as the rationale for its required protection and recognition as Cultural Heritage in Germany (Tauschek 2013: 23).

In Turkey, while the ritual in question is not an entirely forbidden practice there are continuing institutional and social constraints, which serve to limit the public expression of Aleviness. References made by the AABF representative to an Alevi Cultural Heritage and the limitations imposed on Alevi religious life in Turkey offers an insight into the uses of Cultural Heritage discourse and suggests that there is more to Cultural Heritage than the mere preservation of certain aspects of the past. The language of Cultural Heritage and references to intergovernmental institutions such as UNESCO are used by cultural, social or ethnic(ized) groups to express demands for the recognition and representation of their identities. The contested / iterated notion of semah as Alevi heritage in Turkey and Germany indicates the extent and dissemination, both geographically and socially, of the actors involved in the negotiation of Alevi Cultural Heritage. This paper seeks to analyse the multiple ways in which the concept of Cultural Heritage has been used by Alevi organizations in Germany and Turkey. In order to grasp the capacities (and limitations) of the concept of Cultural Heritage in the negotiation of ideas about identity and the nation's past, I will argue that references to Cultural Heritage have to be understood in terms of their political dimensions and social implications (for both civil actors and nation-states). What specific ideas about belonging and cultural or religious alterity are put into practice and rendered true by these policies? In what ways do Alevi communities involved in the process position themselves and act in accordance or opposition to these discourses? What is the ratio of empowerment and containment within these governmentalities of heritage, which celebrate diversity on the one hand, while denying legal recognition on the other?

In order to understand the multiple layers of Alevi heritage discourse in Germany and Turkey the paper first seeks to provide an overview of the institutional and discursive background of Alevi organizations in both countries and in "transnational space" (Sökefeld 2008). Analysis of the development and conceptualization of Alevi Cultural Heritage reveals the very specific imaginations of national and group identities that emerge in heritage regimes. Here also the multiple capacities of heritage policies for identity-formation, the politics of recognition and the governance of diversity are explored, an aspect which requires greater emphasis if critical studies on Cultural Heritage are to resist the tendency towards rather naïve narratives of agency, empowerment, and the representation of minority issues by governments and intergovernmental actors.

\section{Alevis and their Ritual Practice: Organizing Alevism in Turkey, Germany, and Transnational Space}

6 Up until the end of the 1980s Alevi-related matters were comparably less visible in public space and politics than today, a development which is applicable to the case of both Germany and Turkey (Dressler 2013: 12). In Germany, Alevi immigrants were categorized according to their nationality and thus listed on the population census as Turkish citizens. In Turkey Alevism has long remained an unrecognized (or silenced) phenomenon: The Turkish nation-state since the Treaty of Lausanne has been built 
upon a Turkish-(Sunni) Islamic notion of belonging that has invisibilized Kurdish and Alevi identities as non-Turkish and / or non-Sunni respectively (Dressler 2014: 141). However, political and socio-economic transformations occurring since the late 1980s have contributed to the opening of Alevi associations in the larger cities of Turkey and in Western Europe, to where many Alevis had emigrated in the 1960s and 1970s (şahin 2005; Sökefeld 2008). The work of these organizations has largely been tolerated by the state and in 2007 the AKP government proclaiming an "Alevi opening" launched a series of policies aimed at redressing the political position of Alevis (Soner and Toktaş 2011: 420). Various meetings aimed at formulating Alevi demands from the state and negotiating their implementation were attended by representatives of the Alevi communities alongside their state interlocutors (Önraporu 2010: 1). Despite these outward improvements, the possibility of expressing an Alevi identity distinct from Sunni Islam has remained fundamentally limited by the enduring dominance of the Turkish-nationalist (Sunni-Muslim) model of identity (Dressler 2014: 140). It is particularly interesting to analyze Turkey's Cultural Heritage policies and practices in the light of the (apparently) changing attitude of the state because the recognition of Alevi Cultural Heritage and its inscription onto the Turkish National Inventory of Heritage has (yet?) to be translated into the parallel recognition of critical political identity demands and rights, concerning, for example, Alevi religious education in public schools or providing public funding for religious infrastructure such as cemevis ${ }^{3}$.

7 In the following section I will provide an overview of the actors involved in the process(es) of defining Alevi Cultural Heritage and, in particular, of the socio-economic developments, which have engendered changes to Alevi ritual practices. It will be argued that such transformations made the emergence of an Alevi ritual as Turkish Cultural Heritage imaginable in the first place.

\section{Alevi Organizations and the Quest for Representation}

Although all of the organizations considered here represent a certain form of Alevism they differ considerably in political outlook and available socio-economic resources (Massicard 2013: 49). However, a point of unification, canalized and (partly) expressed by these Alevi organizations, may be found in the divergence of their devotional service and principles of belief from Sunni Islam. For example, Alevis neither say the five daily prayers [namaz] nor do they fast during Ramadan. In many Alevi communities a salient aspect of Alevi ritual practice is the performance of the cem ritual by men and women together, a factor which continues to be employed by Alevis and Sunni groups as a distinguishing feature used to demarcate their respective differences. ${ }^{4}$

Turkish nationalist ideology and the political structures upon which the Republic was built still translates into an institutional setting that fails to recognize Alevis as a legitimate part of the nation, approaching Alevism as a problem to be addressed by "sometimes less and sometimes more violent politics of coercion and assimilation" (Dressler 2014: 139). This polity finds its expression in the General Directorate of Religious Affairs, Diyanet, a state institution defining, controlling, and organizing legitimate forms of religious life and one which does not recognize Alevism as a religious group distinct from Sunni Islam.

The organizations involved in this "multipolar movement" (Massicard 2013: 51) of Alevi Cultural Heritage-making in Turkey are representative of very different interpretations 
of Alevism, relating, for example, to the highly contested understanding of whether Alevism can be considered an Islamic tradition or a religion in its own right (şahin 2005; Sökefeld 2004). In this sense it is highly remarkable that such a wide range of Alevi actors with quite different agendas were able to unite for the sake of a common Alevit-Bektaşi Cultural Heritage. In order to describe the diverse range of Alevi identities represented by the various associations, Soner and Toktaş employ the binary concept of "modernist-secular vs. traditionalist-religious" groups (Soner and Toktaş 2011: 423). In their terms "traditionalist-religious" organizations like CEM(Cumhuriyetçi Eğitim ve kültür Merkezi) or the Ehl-i Beyt Foundation articulate a more religious interpretation of Alevism. For example, CEM Vakfi seeks the representation and organization of Alevism within state institutions like Diyanet and thus subscribe to a vision of Alevism as a form of Islam (Ibid., 424). In contrast, other organizations defined as "modernist-secular", such as the Alevi-Bektaşi Federasyonu (ABF), fear assimilation with state institutions and thus tend to advocate for the separation of religion and state, a position that would support neither Sunni nor Alevi religious beliefs and practices (Ibid.). Massicard, however, identifies three major axes along which Alevi associations in Turkey are ideologically and practically organized. The Hact Bektaş Veli Anadolu Kültür Vakfi and the Alevi Kültür Derneği for example, as opposed to the aforementioned CEM Vakfi, represent those parts of the Alevi movement that emphasize the folkloristic and cultural aspects of Alevism. Still others like the Pir Sultan Abdal organization have adopted a more political and leftist outlook (Massicard 2013: 49).

11 Parallel to the socio-economic and political developments in Turkey from the 1980s, comparative changes were also occurring in Germany. Of the many different Alevi organizations that emerged the Almanya Alevi Birlikleri Federasyonu (AABF) constitutes the most pertinent case study for consideration in this paper, the question of an Alevi ritual as Cultural Heritage in Germany having been raised by an AABF member (Tauschek 2013: 23). The organization is also an example of what Sökefeld has termed an "opposition diaspora" (Sökefeld 2008: 250). AABF opposition against current Turkish politics towards Alevis emerges from the organizations partial representation of the politics of leftists exiled from Turkey in the 1970s and 1980s. Furthermore, there are many Kurdish speaking Alevis organized within the AABF (Ibid., 230). Institutionally speaking, the AABF holds quite a powerful position, being officially recognized as both a "registered association" [eingetragener Verein] and a "religious community" [Religionsgemeinschaft] in the sense of $\S 7,3$ of the German constitution applicable in some federal states. As such, in concert with the state it is able to organize religious education in German public schools, albeit this influence does not mean that its position and understandings of Alevism are uncontested by other more conservative or religiously oriented organizations. The comparatively privileged legal standing of the AABF sets it apart from other Sunni organizations, which do not enjoy the same degree of institutional integration (Sökefeld 2008: 250).

The institutional position of the AABF is fundamental to understanding the underlying dynamics of its capacity to act as an "opposition diaspora" and criticize the situation of Alevis in Turkey. Sökefeld argues that institutional power alongside the endeavour to distinguish an Alevi identity distinct from Sunni-Turkish Muslims in Germany enabled the AABF to yield the resources for a "transnational politics of identity aiming at [the] formal recognition of Alevis in Turkey" (Sökefeld 2003: 135). The utilisation of the 
sphere of "transnational space" for the articulation of the identity claims of the diaspora community is argued by Sökefeld to be perceptible in the expression of "home orientated issues" i.e. those issues concerning Alevis in Turkey (Sökefeld 2008: 221). The concept of "transnational space" encompasses the multiple connections and interactions of Alevi organizations in Germany and Turkey and opens up a field in which the claims of an Alevi diaspora are made "against the nation-state of origin" (Ibid.,: 250), as illustrated by the use of the discursive framework provided by intergovernmental institutions in the case of Turkey.

\section{Dynamics in Ritual Practice}

13 The socio-economic and political processes of rural-urban and transnational migration, in addition to the increasing degree to which Alevism was being organized in cultural associations, have resulted in fundamental transformations and adjustments of religious practice (Motika and Langer 2005: 76). The public articulation of Alevi identity in Turkey and diaspora contexts marks a shift away from the former strategy of concealment from non-Alevis [takiye] towards the open display of religious and cultural assets, a development which holds true not only for Alevis, but also for other "Alioriented religions" as well (Olsson 1998: 199). The emergence of Alevi associations have been - and still are- accompanied by discussions about the standardization and unification of Aleviness (Sariönder 2005: 164), a process that has been highlighted by the recognition of a common Alevi-Bektaşi Intangible Cultural Heritage. The relatively isolated and scattered geographical location of Alevi communities alongside the absence of a central normative Alevi religious authority has resulted in great variation in ritual practice. Such variation has undermined the struggle for the standardization of ritual practice for the sake of a collectively accepted form of public ritual display. This is exemplified in the performance of the most important congregational ritual among Alevis, the cem ritual, which may vary considerably in length and order. Many Dedes (the religious specialist conducting the rituals) follow an individual approach to the ritual. The prayers and religious hymns may subsequently differ considerably from those used by other Dedes, while the terminology of the different sequences may vary according to the specific historical or regional context of its performance (Langer 2008: 97). The public representation of Alevi religion and / or culture requires the definition of the common denominators of belief and ritual practice (Göner 2005: 128). Thus, the cem-ceremonies currently held in the associations of the big cities in Turkey and in the Diaspora, often omit certain local sequences while others, such as the ritual dance sequence semah, have come to assume a greater significance. Langer, for example, argues that changes have been made to the public display of the juridical part of the ritual, in which inner-communal conflicts are resolved by the Dede. The juridical part was frequently observed to have been removed altogether or reduced to a symbolic act (Langer 2013: 207). In the same manner, Dinçer's analysis of urban cem rituals in Izmir and Istanbul, attended by Alevis from various regions with different mother tongue languages and alternative imaginations of ethnic belonging, revealed the dominance of the semah, as one of the "12 services", vis-à-vis other ritual sequences (Dinçer 2000: 37). The tendency to emphasize specific ritual features, such as the semah, and its public presentation has been argued to have contributed to the "de-sacralisation" of the cem ritual (Massicard 2013: 130). According to the UNESCO Nomination file, 2010 the semah has clear religious connotations when conducted privately as the rhythmic movements 
symbolize the unity of man and God (UNESCO Nomination file 2010: 4). The lifting of one hand towards the sky during the circular movements of the dance, for example, commemorates God's immanence in human beings and the inseparable connection of the two (Ibid.). ${ }^{5}$ Yet, its musical and dancing characteristics are also recognized to "constitute a common language of humanity" (Ibid., 6). Such a focus on the main folkloristic and representative symbols of the Alevi community helps to overcome divergent imaginations of Alevism in the religious and political field. This "selffolklorization" (Massicard 2013: 130) is thus identified as a means of fostering a common Alevi identity without facilitating a corresponding disagreement about contested issues, such as the standing of Alevism towards Islam or Alevism being a religion or culture (Ibid., 134).

Similar dynamics and conflicts are also evident in the German diaspora. Since the publication of the "Alevi Declaration" [Alevilik bildirgesi] in 1989, Alevism was no longer thought of as a "religious creed with secret oral traditions" (şahin 2005: 465), but instead was recognised as a cultural and religious identity distinct from Sunni Islam. The manifesto, in which members of the Alevi Cultural Centre in Hamburg, Germany publicly announced their recognition of the existence of Alevis in Turkey, is considered to have been the first step towards a publicly articulated Alevi identity in Germany and the "reconstitution of Alevism" after the long-practiced takiye (Sökefeld 2004: 139). The transferal of the ritual to the public realm in the context of diaspora consequently also brought about fundamental changes to ritual practice. Comparable to the Turkish context and the changes precipitated by rural-urban migration from the 1960s, similar processes were also discernible in the context of (trans)national migration. Here too the complexity and duration of the cem ritual was reduced, while the public display of the ritual was conducted with the exclusion and emphasis of certain selected parts (Motika and Langer 2005: 99).

The emphasis on the semah dance in the public presentation of the ritual is all but uncontested by Alevis themselves. In the process of ritual transferal and the accompanying (re)invention and (re)interpretation of ritual practice, the question of whether or not Alevism constitutes a religion or culture is continuously negotiated. Furthermore, the definition of Alevism not only differs among various Alevi organizations, but may also shift according to the specific discursive and institutional contexts in which the actors are operating. For example, in order to exercise influence over the question of religious education in public schools, it is first necessary to be recognized as a specific public corporation representing a "religious community" [Religionsgemeinschaft] (Sökefeld 2004: 148). Conversely, the discursive and institutional setting for the safeguarding of ICH requires a definition of ICH as the de-sacralised remains of the past; the aim of safeguarding Cultural Heritage explicitly sets itself apart from safeguarding religious artefacts (Tauschek 2013: 23). If an Alevi ritual is to be considered Cultural Heritage in UNESCO's terms, it has to be, by the very definition of Cultural Heritage, de-sacralised.

\section{Negotiating Alevi Cultural Heritage}

The instruments developed by UNESCO for safeguarding ICH are explicitly directed at “communities, in particular indigenous communities" (UNESCO Convention 2003: \$7). Merkel regards this as an attempt to empower "communities" and correct earlier 
rather exclusive misconceptions of heritage that were directed at aesthetic and monumental representations of human kind's achievements (Merkel 2011: 68). Furthermore, this also allows these "communities" - understood in terms of networks, not limited to specific geographic boundaries - to include diaspora groups as bearers of their ICH (Ibid.). It is noteworthy for the case discussed here that UNESCO perceives the recognition of Intangible Cultural Heritage as "bringing human beings closer together" (UNESCO Convention 2003: §15). This is especially interesting when we also take into consideration the fact that explicit allowances are made for the inclusion of instances in which the actors of designated heritage itself transcend national borders; the criteria for submitting an application recognizes multi-national nominators ${ }^{6}$. Despite this opportunity for a "shared heritage" of Alevi communities across Turkey and the diaspora, the case described here seems to be demonstrative of an alternative position: The nomination sheet for the Turkish Alevi semah neither lists any German Alevi organization, such as the AABF, nor does the AABF recognize the Turkish Alevi semah as part of its Cultural Heritage. ${ }^{7}$ In spite of its intended aspiration of "bringing human beings closer together" the Convention can, to the contrary, be used as a means for demarcating difference.

\section{Theoretical Considerations: Heritage, Power and Belonging}

17 This exclusive notion of heritage becomes even more powerful in the light of a central concept of heritage: "categorization and listing" (Harrison 2013: 6). The alleged character of ICH being less hierarchic or a bottom-up process is undermined by the very mechanisms that implement these ICHs: listing and categorizing always has to apply certain criteria, which inevitably ascribe value while simultaneously devaluating others. This aspect becomes even more apparent if we take into consideration the fact that the nation-state(s), as representatives of Cultural Heritage (next to "indigenous groups"), have to consent to safeguarding measures, providing financial resources and infrastructure (UNESCO Criteria 2012: \$3). In the case discussed here, the political rationale for recognizing Alevi Cultural Heritage as enhancing the nation's diversity without adopting this diversity in a political and legal framework is brought into question.

18 Similarly, in both Turkey and the diaspora, the negotiation of Cultural Heritage between the Alevi "community", the nation-state, and UNESCO renders visible the specific imaginations about the nation, its past, its criteria for belonging, its pluralism or its homogeneity that underpin the construction of Cultural Heritage. Referring to this aspect of heritage policies, Hall has highlighted the evaluating character of Cultural Heritage policies. Heritage, from this perspective, is not only the desire and the practice of preserving certain aspects of the past, but constitutes "the symbolic power to order knowledge, to rank, classify and arrange, and thus to give meaning to objects and things through interpretative schemas" (Hall 2007/1999: 88). These particular formations of knowledge and mentalities of government are embodied in the instruments, strategies, and politics applied. The approach of the "governmentality" of heritage tries to grasp this interrelation of knowledge, power, and the specific governmental understandings, for example, of diversity, which are inscribed in political programmes and political practices and put into play by these very strategies (Rose 1999: 2). Drawing on Foucault's notion of government, which perceives political power as an incoherent assemblage of endeavours to guide, shape, direct, conduct, and 
enhance people in a desirable way (Foucault 2004: 162), Cultural Heritage too may be understood as a part of this assemblage and of the politics of social or national cohesion and diversity management (Coombe 2012; Tauschek 2013: 20). The analytical power of this concept lies in its connection between the individual and government. The conduct of contemporary (neo-liberal) government relies on enhancing individual and collective agents ("communities") ability to act upon themselves, rather using ideas of freedom, self-fulfilment, and responsibility than domination, law or coercion: Governing, in this sense, is

not a way to force people to do what the governor wants; it is always a versatile equilibrium with complementarity and conflicts between techniques which assure coercion and processes through which the self is constructed or modified by himself (Foucault 1993: 204).

This understanding enlarges the analytical framework for this paper in many ways. Firstly, as discussed in the previous section, the dynamics of ritual practice constitute the basis of adjustment for both Alevi actors and state policies. Government here is best understood when the exercise of power is dissociated from domination. The governmentality of Cultural Heritage does not oppress the endeavours and capacities of Alevi actors to publicly display and negotiate their identity demands, but rather recognizes this capacity and adjusts to it with instruments such as heritage policies. With that being said, the construction of heritage may not only be read as an "agentive way to act upon one's own world" (Brosius and Polit 2011: 3), but also as a device of government (among many others) to govern ethnic(ized) or religious minorities in certain ways. If we are to grasp the implications of heritage formation on empowerment and exclusion, the aspect of agency has to be discussed with deference to the complex array of identity demands and the (possibly disciplining) political structures that provide the means "to act upon one's own world".

\section{Alevi-Bektaşi Cultural Heritage in Turkey: Making an Alevi "Community"}

The understanding of God-human unity and that everything will return to God has found its way in semah through circular movements which is derived from the movement of celestial bodies. Provided that this element is included in the Representative List [of Intangible Cultural Heritage (ICH)] the authentic understanding of nature and universe, the symbolism and the conceptual depth of semah will better contribute to the universal awareness in ICH.

The human-centred perception of the world and the universe and humanist philosophy of semah are values which can contribute to the intercultural dialogue (UNESCO Nomination file 2010: 6).

The above cited quotation is taken from the 2010 application file of various AleviBektaşi organizations in Turkey seeking to assign the semah - a sequence from the cem ritual - onto UNESCO's protective list. The ritual dance's subsequent successful inscription on the Representative List of Intangible Cultural Heritage also resulted in its official recognition as a part of Turkish "folklore", "enriching traditional music culture in Turkey" (UNESCO Nomination file 2010: 6). Although nation-states have to support the nomination process, a criterion for granting ICH status is that the actors, groups or communities concerned participate in the application process (UNESCO Criteria 2012: $\S 3)$. This aspect requires an understanding of the comparative benefits of creating Cultural Heritage for both state and non-state-actors. Especially in the context of the 
Alevi-state relationship, this is particularly interesting to investigate as the (legal and social) position of Alevis in the Turkish state is subject to heavy criticism by human rights actors and Alevi NGOs in Turkey and abroad.

Alevi communities in Turkey are in an ambivalent position. On the one hand, the Law on Dervish Lodges [Tekke ve Zaviye Kanunu] instituted in 1925 and remaining in effect, forbade all forms of religious orders [tarikat] and associated ritual practices, clothing, and titles. The law also had wider implications on Alevi ritual practice and in fact constitutes one of the main issues in the struggle for the recognition of Alevi communities in Turkey and the diaspora (Sökefeld 2008: 236ff.). On the other hand, in accordance with UNESCO Criteria, 2012 a number of Alevi-Bektaşi cultural organizations have been included in the application process for the recognition of their Cultural Heritage (UNESCO Nomination file 2010: 13). The assemblage of these diverse associations and the public practice of rituals (under the term "Alevi") has largely been tolerated by the Turkish authorities while the revision of the aforementioned law on Dervish Lodges has also been under consideration ${ }^{8}$. Since 2007 Alevis may also be exempt from compulsory religious education in public schools following a decision by the European Court of Human Rights, which found Turkey to be in breach of the article relating to The Right to Education of religious and minority identities (Dressler 2013:

7) ${ }^{9}$. Yet, tolerating the work of Alevi-Bektaşi NGOs does not amount to the legal and political recognition of the Alevi communities as religiously different subjects with the right to religious self-representation.

Alongside representatives of the state party, various NGOs of Alevi-Bektaşi character, research institutes, and academics are involved in the construction of heritage in Turkey (UNESCO Nomination file 2010: 13f.). The Ministry of Culture and Tourism is involved in the process of "heritagization" (Graham 2007/2002: 250), acting on behalf of the state party. According to UNESCO Criteria, the ministry is required to act in concert with the "concerned communities" (UNESCO Criteria 2012 \$3). This "concerned community" is represented by various Alevi-Bektaşi $\mathrm{NGOs}^{10}$ and by local authorities such as Nevşehir Hacıbektaş Bakanlığı. The fact that the Ministry of Culture and Tourism has been instituted by the nation-state to undertake overall responsibility of the process is indicative of the specific folkloristic and cultural understandings being applied to heritage issues; Alevi identity demands formulated within this realm thus fail to address the serious issue of belonging, rather detaching such demands from their political origin, as will be argued in further detail below.

It is of significance to note that only four out of the seventeen NGOs involved in the process operate under the heading "Alevi", while the others refer in their naming to the saint Hacı Bektaş or to tribal associations such as Tahtaci. The close association between "Alevi" and "Bektaşi" in many of these denominations - also evident in the naming of the ritual in question as "Alevi-Bektaşi" heritage - may denote a certain form of state-controlled difference: As Dressler has pointed out, the term Alevi-Bektaşi is used mostly by Turkish speaking Alevis (Dressler 2013: 19). Although Alevis and Bektaşis share a lot of their ritual practices and belief systems and as such may be imagined as one community, the term also annihilates the institutional, social, and geographic differences between these groups. In the Ottoman period, the Bektaşis as a religious order [tarikat], served a specific administrative purpose via its zaviyes [dervish lodges] and affiliations with the janissary corps of the Ottoman army. In contrast, Alevis - or more appropriately, the communities in Anatolia that have come to be 
identified as the predecessors of present-day Alevis, historically referred to as Kızllbaş ${ }^{11}$ - were socially and economically marginalized and temporarily heavily persecuted due to their alliances with Shiite missionaries from Iran (Ibid., 18). However, already towards the end of the $16^{\text {th }}$ century a state-favoured process of socio-economic assimilation had been set in motion, linking the Kızılbaş communities to the Bektaşis in order to undermine sectarianism among the Kızllbaş of Anatolia (Faroqhi 1992: 176). Still, as Kieser argues, there have never been any strong ties between Kurdish speaking Kızılbaş from southeast Anatolia and the Bektaşis residing in central and western Anatolia (Kieser 2003). Neither can it be said that all Turkish Alevi ocaks ${ }^{12}$ maintained any form of relations with the Bektaşi Order. According to Dressler, the emphasis on an Alevi-Bektaşi synthesis may be read as a means of strengthening Alevi agency in the Turkish public sphere by weakening the notion of social and cultural differences between Turkish and Kurdish speaking Alevis and the Bektaşis (Dressler 2013: 19).

Although the character of these denominations may be losing their ideological and discursive clarity ${ }^{13}$, the organizations in charge of constructing an Alevi-Bektaşi Heritage refer to themselves in the nomination file as an "Alevi-Bektaşi Order" thereby excluding any alternative form of Alevism, which refuses to subscribe to the Bektaşi notion of Alevi identity: The "Alevi-Bektaşi Order has distinguished itself from the mainstream Alevi belief system, with respect to its roots, formation processes and current cultural background" (UNESCO, Nomination file: 2, my italics). The specificities that comprise the "current cultural background", however, remain ambiguously defined. The distinction drawn between the "Alevi-Bektaşi Order" and "mainstream Alevism" regarding their formation processes and current background suggests a stratification, which orders various forms of Alevism and explicitly sets the Alevi-Bektaşi Order apart from other (unnamed) interpretations of Alevism. Despite this distinction, which acknowledges the Alevi-Bektaşi Order as the cultural-bearer of an Alevi Heritage, the UNESCO Nomination file, 2010 also emphasizes the "richness in semah culture" (UNESCO Nomination file 2010: 4) and names various "Alevi Bektaşi communities" as "bearers and practitioners of the semah tradition" (Ibid., 2). The Nomination file, 2010 requires the identification of the geographical location of the communities and groups concerned with the designated heritage. Although the Alevi-Bektaşi Order is distinguished from mainstream Alevism, the geographical range afforded to Alevi communities extends to almost all of the Anatolian region. Such an expansive (geographical) definition, therefore, encompasses very different Alevi and Bektaşi groups like the Babağan Bektaşis and Alevi ocaks from central and eastern Anatolia, which distinguish themselves from one another through the principle of initiation (Babağan Bektaşis) or descent as means of belonging. At least for some of the Anatolian ocaks it is - historically speaking - difficult to uphold any relationship with the Bektaşi Order (Dressler 2013: 17). However, a consequence of involvement in Cultural Heritage policy-making has been the alliance of different organizations representing diverse Alevi identities and interests under the label of "Alevi-Bektaşi". The list of the "concerned community organization(s) and representative(s)" (UNESCO Nomination file 2010: 13) also contains those associations like CEM Vakfi and the Pir Sultan Abdal Kültü̈r Dernekleri, which politically and religiously follow quite different agendas. CEM $V a k f i$, for example, represents the position of Alevism as an Islamic tradition, while the Pir Sultan Abdal Foundation clearly distances itself from such claims, perceiving Alevism to be a religion on its own right (Dressler 2013: 7). 
In order to bring such divergent actors together, the heritage of semah is thus designed and described accordingly. Distinguishing between içeri and dışarı semah [private and public semah] the ritual dance is defined to comprehend both its religious and folkloristic / cultural meanings. Recognition that "It is not desirable to perform içeri semah in front of those without faith" (UNESCO Nomination file 2010: 5) represents the position of Alevi organizations wishing to preserve the religious and sacred character of the ritual. The dışarı semah, in contrast, addresses organizations like the Hacı Bektaş Veli Kültür ve Tanitma Dernekleri that rather focus on the folkloristic aspects of Alevism for the purpose of its presentation to outsiders and the schooling of younger generations (Massicard 2013: 49). Interestingly, the recognition of semah as a commemoration of the prophet Muhammad's meeting with the so-called kurklar meclisi [the assembly of the forty saints of Alevism] is not mentioned in the description of the semah as Alevi-Bektaşi heritage. Although many Alevis believe that it was during this meeting the semah was danced for the first time (Langer 2008: 98), the connection of the dance with the prophet Muhammad is omitted from the document. In the context of negotiating an understanding of Alevism as a religion or culture this may be once again indicative of the rather de-sacralised and folkloristic interpretation of the semah.

The question of folklore is quite an important issue in the Alevis struggle for recognition. First and foremost, it is one that is directly linked to financial demands regarding the payment of religious personal by the state. While Sunni Imams are paid by the state, Alevi religious authorities cannot be sponsored publicly, as the cemevi is not considered a "prayer house", but a "cultural house" (Dressler 2013: 10). In response to a question about the situation, the former Turkish Prime Minister Erdoğan replied:

Whichever Alevi I meet says, we are Muslims. The prayer place for Muslims is the mosque. Alevism is not a religion [din]. Therefore one cannot compare [Islam and Alevism]. If we made this distinction, why should we divide Turkey? One is a house for prayer; the other is a culture house. Cem houses cannot receive the same [financial] assistance that the mosques receive. If there is somebody who wants to support cem houses this cannot be hindered (cited in Sökefeld 2008: 245).

Although the UNESCO Nomination file explicitly accepts the semah as part of the cem ritual - and by implication acknowledges that it is part of the religious practices of Alevi-Bektaşi adherents - there are also strong folkloristic connotations; the ritual is also ascribed the function of "enriching (the) traditional music culture of Turkey" (UNESCO Nomination file 2010: 6). As the quote at the beginning of this section suggests, alongside this rather vernacular characterization of semah, the ritual sequence is also described as maintaining a "humanist philosophy", which "can contribute to intercultural dialogue" (Ibid.). Both the vernacular and universal aspects of semah serve to detach the ritual dance from its religious context. In the same manner, the participation of both men and women together in the dance has also assumed symbolic significance (Ibid., 5): Contemporary gender equality issues are expressed through the nomination file as the dance and the designated Cultural Heritage are understood to signify the explicit rejection of "gender discrimination" by all Alevi-Bektaşi communities (Ibid.). This aspect highlights the character of Cultural Heritage as inherently linked to contemporary issues and needs (Graham 2007/2002: 251). Likewise, the ICH Convention itself, through the principle of heritage as empowering the instrument of protection strikingly reveals the capacity of heritage as a "useable past" (Merkel 2011). As Intangible Cultural Heritage the semah has to fulfil multiple functions yielding a performativity, which explicitly raises "awareness"; 
awareness for "local literature" in addition to the safeguarding of the Intangible Cultural Heritage of human kind in general (UNESCO Nomination file 2010: 6).

Despite the recognition of the diversity of Alevi groups and communities in Turkey, the state nevertheless continues to privilege one particular form of organization: those who are willing to integrate themselves into the Alevi-Bektaşi imagination of belonging. Here the state party becomes visible as a powerful actor in this allegedly bottom-up process. A fundamental paradox of the process remains that despite the $\mathrm{ICH}$ Convention's intended inclusion of "indigenous communities", without the state these communities have no opportunity of accessing UNESCO's protective mechanisms for Cultural Heritage. An unchanged condition institutes the concerned state party - in Turkey represented by the Ministry of Culture and Tourism - with the overall responsibility for listing the element in question on the National Inventory of the Intangible Cultural Heritage (UNESCO Criteria 2012: \$3). This aspect accentuates the necessity of engaging state interest in safeguarding certain (vernacular) communities' Cultural Heritage.

\section{Alevi Cultural Heritage in the "Opposition Diaspora"}

In May 2013 an informational conference held for parties interested in the application and nomination process of Intangible Cultural Heritage was organized by a regional UNESCO bureau in Lübeck, Germany. At this conference a representative of the AABF in Hamburg asked about the possibility of inscribing the Alevi semah ritual on the list (given the prohibition of its performance in Turkey) (Tauschek 2013: 23). No mention, however, was made of the fact that the ritual had already been inscribed on the Representative List. The omission of this detail was perceived to be of little consequence to the AABF organizers ${ }^{14}$ who did not regard their interests (and indeed their Cultural Heritage) as being legitimately represented by either the Turkish state or by (some of) the Alevi-Bektaşi communities involved in the process of heritagisation in Turkey. The recognition of an Alevi-Bektaşi Cultural Heritage in Turkey by UNESCO has done little to change the general perception of AABF actors that Alevis in Turkey still do not enjoy the same religious freedoms as their Sunni Muslim counterparts or in comparison to Germany.

These findings reveal the inherently dissonant nature of heritage, a dissonance, as Ashworth points out, that is less caused by vague or inconsistent definitions of the term itself (Ashworth 2011: 19), but by its constructed and thus easily contestable character. According to Tunbridge and Ashworth, such a dissonance may be caused by the geographical diffusion of populations and cultures (Tunbridge and Ashworth 2007: 225). I do not wish to imply here that the notion of Alevi ritual heritage in Germany is somehow "misplaced" or "in the wrong place" (Ibid.) as an aspect of this dissonance as such a perspective would misguidedly reproduce the highly normative idea of heritage belonging to a certain territory or a certain nation. An understanding of the negotiation of heritage in "transnational space", however, allows us to overcome some of the limitations inherent in the concept of original belonging; dissociating heritage from homogeneous, national or territorial understandings of origin rather facilitates an insight into heritage as a dissonant product of social practice and negotiation (Falser and Juneja 2013: 24). 
31 The possibilities and constraints for reaching a shared consensus for the safeguarding of Cultural Heritage in the context of geographically dispersed communities with an (assumed) common heritage has been discussed by Merkel (Merkel 2011: 69). However, Merkel does not adequately take into consideration the possibility of intra-communal conflict over the question of legitimate representation and the ownership of heritage. Yet, in the case of Alevi Cultural Heritage in Germany and Turkey this constitutes an important issue for deliberation. In the particular case of semah being recognized as Alevi-Bektaşi heritage in Turkey, the question of the legitimate governance and representation of heritage emerges: AABF actors in Germany do not perceive their heritage as being protected so long as it is represented by the Turkish state and certain Alevi-Bektaşi organizations. ${ }^{15}$ Although the AABF maintains quite close relations with some of the organizations involved in the heritage process in Turkey, in Germany they nevertheless promote their own political agenda for safeguarding Alevi Cultural Heritage. Intra-communal ruptures between German and Turkish Alevi organizations become visible in this case because the UNESCO instrument designed for advancing their particular recognition fails to account for these competing perceptions of legitimate representation.

It is here in the different political and geographical positions occupied by Alevi organizations involved in the negotiation of Alevi Cultural Heritage that the dissonance of heritage emerges. The argumentation of the AABF representative, rather than offering an insight into how such dissonance may be resolved or harmonized, instead is indicative of the way in which it is "turned into a constructive imagination of identity" (Graham 2007/2002: 252). Reference to the semah ritual sequence as Alevi Cultural Heritage and to the limitations placed on the performance of the ritual in Turkey serves to criticize the ongoing marginalization of Alevi identities in Turkey. The point here is, of course, not to argue about the issue of whether or not the semah - as it has been publicly presented and recognized as Cultural Heritage - can indeed be regarded as having been "forbidden". Critical analysis does not negate the assertion of a marginalized and excluded Alevi collective identity by subtle and less subtle methods. Rather, the statement is to be taken - analytically - at face value in order to grasp the underlying understandings of Cultural Heritage and the corresponding notions of nation, community, and belonging it elicits.

Formulating an endeavour for safeguarding the semah "against the nation state of origin" (Sökefeld 2008: 250) serves to criticize current political practice in Turkey, which continues to deny the recognition of Alevism as a legitimate part of the nation with distinct characteristics from Sunni Islam. The expression "being forbidden" thus employed by the AABF representative in connection with the cem-ceremonies of which the semah constitutes an important part, alludes to the specific form of diversity politics exercised in Turkey. The ritual is tolerated and under the label of Cultural Heritage even promoted as folklore serving to enrich Turkey's cultural diversity. Yet, what is at stake in the struggle for recognition is the attainment of comparative equality (in religious terms) with Sunni Islam (Sökefeld 2005: 226). References to Cultural Heritage and the endeavour to ensure its safeguarding thus enables the AABF to hint at these political deficits in an intergovernmental arena. As Merkel points out, the negotiation of Intangible Cultural Heritage in contexts of migration and nationally separated communities enables the groups concerned to question the legitimate 
representation (or usurpation) of the communities' heritage by the nation state(s) involved:

Even where direct human rights abuse is not an issue, legitimacy of government in representing the interests of the living cultural traditions of communities might be challenged or questioned by the groups concerned (Merkel 2011: 69).

The issue of Human Rights generally constitutes an important component of the AABF's critique of Turkish policies towards Alevis (see, for example, Alevitische Gemeinde Deutschland e. V. 2013: 2), and yet it was not invoked in this particular context by the representative of the AABF. Still, references to intergovernmental regimes such as UNESCO provide the discursive and institutional framework for the articulation of alternative versions of Alevi heritage in the Diaspora and thus challenge other perceived illegitimate representations of this heritage. An Alevi heritage that sets itself apart from the existing Alevi-Bektaşi heritage therefore also demonstrates the refusal to subscribe to a dominantly Turkish-speaking notion of Alevism or be assimilated into the folklorized cultural heritage as it is expressed in Turkey.

Furthermore, the concept of Intangible Cultural Heritage is useful for the AABF as it fits in with their political programme on integration in Germany. The humanist ideas of Alevism, which also finds its representation in the Turkish-Alevi nomination form for semah, is frequently invoked in integration discourse in Germany. AABF actors insist on the fact that Alevi values are far less different from German values than those of Sunni Muslims (Sökefeld 2008: 250). This, in turn, facilitates an argument for the categorization of semah on the German National Inventory of Cultural Heritage, a necessary move with regards to the conditions established by UNESCO Criteria, 2012 if Intangible Cultural Heritage status is to be granted. Here too, the agency of the nation-state in the process of heritagisation may heavily influence or even prevent Alevi endeavours. During the above-mentioned conference, a representative from the ministry in charge expressed her doubts about the prospective recognition of the semah ritual as Cultural Heritage, emphasizing the position that religious elements were generally excluded from the nomination process (Tauschek 2013: 24). Thus, safeguarding the semah ritual within UNESCO's terms requires its de-sacralisation. Such a cultural understanding of the cem ritual in general and the semah dance in particular is not uncontested - by either Alevis in Germany or in Turkey. Yet, as Sökefeld argues, the discursive and institutional contexts of both countries differ considerably. A cultural and folkloristic notion of Alevi ritual practice in Turkey, as the Erdoğan quote above indicates, is from the viewpoint of the AABF almost equal to its negation (Sökefeld 2005: 225). This also explains how the ritual may be interpreted as being "forbidden" in Turkey, while simultaneously recognized as Cultural Heritage. In Germany, on the other hand, such a culturalized comprehension of the term does not necessarily bear the same negative or pejorative connotations, although the position of the AABF is by no means unchallenged by other Alevi organizations in Germany (Ibid.).

\section{Heritage, Empowerment and Discipline}

As has been made clear, references to Intangible Cultural Heritage in Turkey and Germany may serve vernacular communities or marginalized groups in society by protecting elements of their culture perceived to be in danger. Wulf underlines the "symbolic meaning" of Cultural Heritage for the formation and reassertion of 
community because it fosters a sense of common values, practices or roots (Wulf 2011: 83). This aspect of heritage with which members of certain groups identify, must be stressed here because it is integral to comprehending the underlying rationale of UNESCO's Intangible Cultural Heritage Convention. With regard to the aims of the convention, Merkel points out that a "psychological sense of ownership" can generate activity for discovering, documenting, and researching Cultural Heritage (Merkel 2011: 60). In these terms, Brosius and Polit also draw attention to the aspect of Cultural Heritage that enhances a community's awareness of its heritage and its capacity to articulate identity demands vis-à-vis the nation-state:

[T]rading rituals as one's own cultural product - thus turning ritual into heritage - does not mean to render these rituals dead in the sense that it mummifies them. Instead, this is to be understood as an agentive way to act upon one's own world (Brosius and Polit 2011: 2)

Such accounts emphasize the empowering potential gained through the construction of Intangible Cultural Heritage for (vernacular) groups. The enhancement of agency that it entails (or intends to entail) plays a critical role in the evaluation of UNESCO's instruments. The authors cited here underline the capacity of ICH to act as a cultural resource. This is especially important in the context of migration and diasporas, because Intangible Heritage is not necessarily place-bound in the same way as other forms of heritage such as monuments and the like (Ibid.: 3 ).

This latter point is applicable to the case study described in this paper: The Alevi diaspora in Germany may refer to the same ritual as their own particular heritage, just as other Alevi communities had done in Turkey before them. Due to the specific character of the Alevi community in Germany - as an "opposition diaspora" (Sökefeld 2008: 250), represented in this context by the AABF - it may be said that UNESCO and its instruments provided the discursive and institutional framework for the articulation of a version of semah heritage in Germany. Although Alevi heritage in Germany is not yet recognized as such, it is possible to acknowledge the argument that reference to a claimed (Alevi) heritage may be potentially empowering. Within the rationale of semah as Alevi Cultural Heritage in Germany lies a critique of the still marginalized position of Alevis in Turkey. Although the AKP government officially launched a democratic "Alevi opening" in 2007, aimed at improving the relationship between the government and the Alevi population, reference to UN bodies like UNESCO and to international legislation like the Human Rights Convention may serve yet again to enhance the visibility of ongoing subtle and less subtle forms of suppression.

However, acceptance of this perspective on the empowering capacities of Cultural Heritage policies tends to overestimate UNESCO's intergovernmental influence vis-à-vis nation-states. It takes for granted the idea that policies on "minorities" (of all kinds) yield empowering and liberating forces for the good of these very "minorities". Such an approach fails to grasp the disciplining aspects of these policies, which not only empower, but simultaneously inscribe a certain understanding of "minority" identity that renders them detached from a perceived political centre represented by the "majority"16. Although UNESCO provides the AABF with the language and institutions to articulate its own diasporic heritage, it is not yet clear whether the German authorities in charge would inscribe the semah on the National Inventory of Intangible Cultural Heritage, a necessary measure if it is to be also inscribed on UNESCO's list. The point at which state parties join in the process of heritagisation is also the point of potential (re)nationalisation and exclusion. In Germany the issue of Alevi heritage may 
result in the need to once again redress the question of Germany being an "immigration country" [Einwanderungsland]. The negotiation of diversity and pluralism at stake in Germany differs from the situation in Turkey. In the latter case, AleviBektaşi heritage has already been awarded through its UNESCO-endorsed inscription on the Representative List and the Turkish National Inventory of Heritage. Yet, recognition of pluralism and the Alevi-Bektaşis' contribution to Turkey's cultural diversity does not touch on sensitive political issues, such as the recognition of Alevism as a religious community. The semah as Alevi Cultural Heritage is perceived to be folklore and as such is easily accommodated within the Turkish-nationalist narrative of unity, which allows diverse forms of cultural expression to exist, but without corresponding acknowledgement in a legal framework. In this setting of "disciplined liberalization" (Tambar 2014: 84), claims for Alevi religious education in schools or for a state-paid religious infrastructure may continue to be denied.

The heritage of vernacular groups or "indigenous communities" (to employ the language of UNESCO) indeed produces some forms of cultural diversity and visibility. However, as the nation-state remains the ultimate arbitrator in decisions relating to the National Inventory of Cultural Heritage, this diversity continues to be articulated in the form of "domesticated diversity" (Göner 2005: 127). Diversity as it thus emerges is not only invoked to fulfil an ideological or political purpose, but the particular form it takes is also the result of the intrinsic nature of heritage itself and its capacity to categorize, list, include and exclude (Harrison 2013: 164). Furthermore, the recognition of Alevis on a comparative legal-political basis with Sunni Islam, seems to have been traded for cultural recognition. In such contexts, Ashworth argues that heritage discourse may be "used deliberately to render insignificant the ideas and practices that could potentially challenge or distract a dominant ideology" (Ashworth 2011: 34). He speaks of "museumification" to denote this specific aspect of heritage policies, which transforms cultural expressions of (political / social / religious / ethnic[ized]) minorities into folklore thereby undermining their capacities for political participation and resistance (Ibid., 33).

Ashworth's argument challenges the emphasis on agency, which is supposed to be enhanced by UNESCO's instruments. His idea of "museumification" and "vernacularization" (Ibid., 34) rather contests the liberal notion of the ability of individuals and communities "to act upon their own world" (Brosius and Polit 2011: 2) and hints at the (marginal) position that these groups adopt in heritage discourse or which is ascribed to them. The sets of knowledge about the past and diversity, embodied in the policies and practices of Intangible Cultural Heritage, thus renders very specific imaginations about belonging legible, firm, and true. Alevi-Bektaşi Cultural Heritage may enrich Turkey's diversity, but it is thought of as a rather (dead and indeed "mummified") folkloristic facet, detached from its political context. An understanding of Cultural Heritage as governmentality enables us to grasp the hegemonic knowledge inscribed in Heritage policies and put into practice by its "safeguarding" measures. This perspective allows us to analyse the above-mentioned aspects of "museumification" and "vernacularization" as forms of political conduct that rely on a wide assemblage of instruments guiding, directing, enhancing, and shaping the populations' will to act upon itself. What was labelled a "discursive and institutional frame" providing the language and the modes of organization in heritage construction, within this light is reconsidered as a mode of governmental conduct that 
does not draw on the semantics of rule, law, or coercion to guide the population in desired ways. In the present context of ongoing physical political violence in Turkey it is particularly important to emphasize that the recognition of subtle forms of political power does not mean to imply that other less subtle forms of conduct or even violent interventions have ceased to exist. However, taking a perspective on the close link between power and knowledge enables us to grasp both the governmental mind in its capacity "to rank, classify and arrange" (Hall 2007/1999: 88) knowledge and the communities' adjustments to these schemas. The "communities" addressed, on the other hand, are the very agents that put these schemas into practice: The policies on Cultural Heritage, for example, produce forms of Alevi-Bektaşi subjectivities that intersect with "modernist-secular" or "traditionalist-religious" cleavages, the terms of which are employed to characterize the various organizations active within these policies (Soner and Toktaş 2011: 423). Rather, the governmentalities of Cultural Heritage turn them into productive forces that negotiate an Alevi-Bektaşi Cultural Heritage. Furthermore, this negotiated Cultural Heritage may also be recognized by diverse organizations that differ considerably in their comparative positions, for example, as demonstrated by the respective views expressed by CEM Vakfi and the Pir Sultan Abdal Kültür Dernekleri on the issue of Alevism as an inner Islamic tradition or a religion in its own right (Dressler 2013: 7).

This approach also comes to terms not only with the focus on community empowerment in ICH discourse, but also with the constitution of Alevism as a socioreligious problem of a (nationalist / neoliberal) government. The ostensible tension and the alleged binary distinctions between liberation and control, inclusion and exclusion, empowerment and containment, can be analysed as a form of political conduct that engenders very specific sets of knowledge about belonging and diversity, which recognizes this pluralism as Cultural Heritage, but does not translate it into equivalent political and legal recognition. The "communities" to be empowered play a crucial role in the enactment of these forms of knowledge in order to render them true (Rose 1999: 167). The institutions and language provided by UNESCO's heritage measures make one "community" of heterogeneous Alevi-Bektaşi organizations intelligible in the first place and produce the very subject of cultural difference it comes to represent. Furthermore, the "communities" sustain the regimes of heritage as they "contribute to the universal awareness on ICH" (UNESCO Nomination file 2010: 6).

UNESCO's heritage regime and all the positive and empowering semantics it brings to bear may thus be scrutinized as creating certain subjectivities, certain emotions, and certain behaviours that are inherently directed towards heritage itself. This perspective not only uncovers "new domains of governance and intervention" (Coombe 2012: 382) in the politics of Cultural Heritage, but also allows us to better understand the fact that heritage construction encompasses more than mere empowerment or the emotional need for preservation. As has been argued in the case of Alevi-Bektaşi Intangible Cultural Heritage in Turkey, this heritage may engender vernacularization or "museumifiction" of the past, which stratifies cultural life and religious expression in certain ways and renders them detached from the present, as Ashworth has observed (Ashworth 2011: 35). This has significant political implications on the Alevi struggle for recognition and cannot be grasped when the multiple forms of influence on peoples' behaviour, desire, opinions and so forth are excluded from a discussion on heritage and its empowering and disciplining forces. 


\section{Conclusion} civil actors in Turkey. As the promotion of Alevi-Bektassi Cultural Heritage is not accompanied by legal recognition, "museumification" becomes an interrelated notion of heritage, detaching vernacularized groups from present, critical questions about political participation and human rights. This facet of heritage's performativity and its use for a nationalist narrative in Turkey requires the analysis of heritage as a mode of governmental intervention and guidance, which draws on enhancing activities in certain desirable ways. Increasing references to cultural heritage in politics, scholarship, and by NGOs, therefore, have to be understood and explored within the context of the multiple functions that they perform: On the one hand, for identity demands and empowerment; and, on the other hand, for political intervention and new forms of subjectivity. 


\section{BIBLIOGRAPHY}

Alevitische Gemeinde Deutschland e.V. (2013) Alevitisches Leben in der Türkei. Diskrimminierung im Alltag, Köln, AABF.

Ashworth, Gregory J. (2011) "Heritage in Ritual and Identity", in Brosius, Christiane; Polit, Karin (eds.), Ritual, Heritage and Identity. The Politics of Culture and Performance in a Globalized World, London, Routledge, pp. 19-38.

Brosius, Christiane; Polit, Karin (2011) "Ritual, Heritage and Identity in a Globalized World", in Brosius, Christiane; Polit, Karin (eds.), Ritual, Heritage and Identity. The Politics of Culture and Performance in a Globalized World, London, Routledge, pp. 1-18.

Coombe, Rosemary J. (2012) “Managing Cultural Heritage as Neoliberal Governmentality”, in Bendix, Regina F.; Eggert, Aditya; Peselmann, Arnika (eds.), Heritage Regimes and the State, Göttingen, Universitätsverlag, pp. 375-387. URL: http://ssrn.com/abstract=2467159.

Dinçer, Fahriye (2000) “Alevi Semahs in Historical Perspective”, in Dans Müzik, Kültür, Folklora Doğru, Istanbul, Boğaziçi University Press, pp. 32-42.

Dressler, Markus (2014) “'Our Alevi and Kurdish Brothers' - Some Remarks on Nationalism and Minority Politics in Turkey”, in Omarkhali, Khanna (ed.), Religious Minorities in Kurdistan: Beyond the Mainstream, Wiesbaden, Harrassowitz, pp. 139-157. URL: http://www.academia.edu/7514727/ _Our_Alevi_and_Kurdish_Brothers_-

_Some_Remarks_on_Nationalism_and_Minority_Politics_in_Turkey.

Dressler, Markus (2013) „Was ist das Alevitentum? Die aktuelle Diskussion und historische Traditionslinien", in Langer, Robert; Ağuiçenoğlu, Hüseyin; Motika, Raoul; Karolewski, Janina (eds.), Ocak und Dedelik. Institutionen religiösen Spezialistentums bei den Aleviten, Frankfurt a.M., Lang, pp. 6-30.

Dressler, Markus (2013 b) Writing Religion. The Making of Turkish Alevi Islam, Oxford, University Press.

Falser, Michael; Juneja, Monica (2013) „Kulturerbe - Denkmalpflege: transkulturell. Eine Einleitung", in Falser, Michael; Juneja, Monica (eds.), Kulturerbe und Denkmalpflege transkulturell. Grenzgänge zwischen Theorie und Praxis, Bielefeld, Transcript, pp. 17-34.

Faroqhi, Suraya (1992) “Conflict, Accommodation and Long-Term Survival. The Bektashi Order and the Ottoman State (sixteenth-seventeenth centuries)", Revue des Études Islamiques LX, pp. 9-29.

Foucault, Michel (2004) Sicherheit, Territorium, Bevölkerung. Geschichte der Gouvernementalität I. Vorlesungen am Collège de France 1977-1978, Frankfurt a.M., Suhrkamp.

Foucault, Michel (1993) “About the Beginning of the Hermeneutics of the Self”, Political Theory 21, 2, pp. 198-227. URL: http://www.jstor.org/stable/191814.

Göner, Özlem (2005) “The Transformation of the Alevi Collective Identity”, Cultural Dynamics 17(2), pp. 107-139. URL: http://dx.doi.org/10.1177/0921374005058582.

Graham, Brian (2007 [2002]) “Heritage as Knowledge: Capital or Culture?”, in Smith, Laurajane (ed.), Cultural Heritage. Critical Concepts in Media and Cultural Studies vol. 2, London and New York, Routledge, pp. 249-268. (Original URL: http://dx.doi.org/10.1080/00420980220128426). 
Hall, Stuart (2007 [1999]) “Whose Heritage? Un-settling 'The Heritage', Re-imagining the PostNation”, in Smith, Laurajane (ed.), Cultural Heritage. Critical Concepts in Media and Cultural Studies vol. 2, London, Routledge, pp. 87-100. (Original URL: http://dx.doi.org/ 10.1080/0952882990857681).

Harrison, Rodney (2013) Heritage. Critical Approaches. New York, Routledge.

Karakaya-Stump, Ayfer (2013) “The Vefā'iyye, The Bektashiyye and Genealogies of 'Heterodox' Islam in Anatolia: Rethinking the Köprülü Paradigm”, Turcica 44, pp. 279-300. URL: http:// dx.doi.org/10.2143/TURC.44.0.2988853.

Karolewski, Janina (2005) „'Ayin-I Cem’. Das alevitische Kongregationsritual: Idealtypische Beschreibung des “íbadet ve Öğreti Cemi”, in Motika, Raoul; Langer, Robert; Ursinus, Michael (eds.) Migration und Ritualtransfer. Religiöse Praxis der Aleviten, Jesiden und Nusairier zwischen Vorderem Orient und Westeuropa, Frankfurt a.M., Lang, pp. 109-131.

Karolewski, Janina (2008) "What is Heterodox about Alevism? The Development of Anti-Alevi Discrimination and Resentment”, Die Welt des Islams 48, pp. 434-456. URL: http://www.jstor.org/ stable/27798275.

Kieser, Hans-Lukas (2003) „Die Aleviten im Wandel der Neuzeit”, in Tamcke, Martin (ed.), Der Orient am Scheideweg, Hamburg, Kovac, pp. 35-61.

Langer, Robert (2013) “The Transfer of the Alevi Cem Ritual from Anatolia to Istanbul and Beyond", in Shankland, David (ed.), Archaeology, Anthropology and Heritage in the Balkans and Anatolia: The Life and Times of F. W. Hasluck, 1878-1920, Vol III, Istanbul, Isis, pp. 205-213.

Langer, Robert (2008) „Alevitische Rituale”, in Sökefeld, Martin (ed.), Aleviten in Deutschland. Identitätsprozesse einer Religionsgemeinschaft in der Diaspora, Bielefeld, Transcript, pp. 65-108. URL: http://www.academia.edu/4078311/Alevitische_Rituale.

Massicard, Élise (2013) The Alevis in Turkey and Europe: Identity and Managing Territorial Diversity, London, Routledge.

Merkel, Christine M. (2011) “Useable Pasts - Creative Futures: How Normative Recognition Opens New Horizons for Publicity”, in Brosius, Christiane; Polit, Karin (eds.), Ritual Heritage and Identity. The Politics of Culture and Performance in a Globalized World, London, Routledge, pp. 55-75.

Motika, Raoul; Langer, Robert (2005) „Alevitische Kongregationsrituale: Transfer und ReInvention im transnationalen Kontext", in Motika, Raoul; Langer, Robert; Ursinus, Michael (eds.) Migration und Ritualtransfer. Religiöse Praxis der Aleviten, Jesiden und Nusairier zwischen Vorderem Orient und Westeuropa, Frankfurt a.M., Lang, pp. 73-107.

Olsson, Tord (1998) "Epilogue: The Scriptualization of Ali-oriented Religions" in Olsson, Tord; Özdalga Elisabeth; Raudvere Catharina (eds.), Alevi Identity. Cultural, Religious and Social Perspectives, London, Routledge, pp. 199-208.

Önraporu (09/02/2010) “Alevi Çalıştayları Önraporu”, Taraf, (full text).

Rose, Nicolas (1999) The Powers of Freedom: Reframing Political Thought, Cambridge, Cambridge University Press.

Sarıönder, Refika (2005) „Transformationsprozesse des alevitischen Cem: Die Öffentlichkeitritueller Praktiken und Ritualhandbücher", in Langer, Robert; Motika, Raoul; Ursinus, Michael (eds.), Migration und Ritualtransfer. Religiöse Praxis der Aleviten, Jesiden und Nusairier zwischen Vorderem Orient und Westeuropa, Frankfurt a.M., Lang, pp. 163-173. 
Soner, Bayram Ali; Toktaş, şule (2011) "Alevis and Alevism in the Changing Context of Turkish Politics: The Justice and Development Party's Alevi Opening”, Turkish Studies Vol. 12(3), pp. 419-434. URL: http://dx.doi.org/10.1080/14683849.2011.604214.

Şahin, şehriban (2005) “The Rise of Alevism as a Public Religion”, Current Sociology 53, pp. 465-485. URL: http://dx.doi.org/10.1177/0011392105051336.

Sökefeld, Martin (2008) Struggling for Recognition. The Alevi Movement in Germany and in Transnational Space, New York and Oxford, Berghahn Books.

Sökefeld, Martin (2005) „Cem in Deutschland: Transformation eines Rituals im Kontext der alevitischen Bewegung", in Langer, Robert; Motika, Raoul; Ursinus, Michael (eds.), Migration und Ritualtransfer. Religiöse Praxis der Aleviten, Jesiden und Nusairier zwischen Vorderem Orient und Westeuropa, Frankfurt a.M., Lang, pp. 203-226.

Sökefeld, Martin (2004) "Religion or Culture? Concepts of Identity in the Alevi Diaspora", in Kokot, Waltraut; Tölölyan, Khachig; Alfonso, Carolin (eds.), Diaspora, Identity and Religion: New Directions in Theory and Research, London, Routledge, pp. 133-155.

Sökefeld, Martin (2003) "Alevis in Germany and the Politics of Recognition", New Perspectives on Turkey 28-29, pp. 133-161.

Tambar, Kabir (2014) The Reckoning of Pluralism. Political Belonging and the Demands of History, Stanford, Stanford University Press.

Tauschek, Markus (2013) Kulturerbe. Eine Einführung, Berlin, Reimer.

Tunbridge, John. E.; Ashworth, Gregory J. (2007) “Dissonance and the Uses of Heritage”, in Smith, Laurajane (ed.), Cultural Heritage. Critical Concepts in Media and Cultural Studies vol. 2, London and New York, Routledge, pp. 206-248.

Wulf, Christoph (2011) "Performativity and Dynamics of Intangible Cultural Heritage", in Brosius, Christiane; Polit, Karin (eds.), Ritual, Heritage and Identity. The Politics of Culture and Performance in a Globalized World, London, Routledge, pp. 76-94.

\section{Websites}

UNESCO Criteria 2012: http://www.unesco.org/culture/ich/index.php?lg=en\&pg=00173\#TOC1.

UNESCO Nomination file 2010: http://www.unesco.org/culture/ich/index.php?

lg=en\&pg=00011\&RL=00384.

UNESCO Convention 2003: http://www.unesco.org/culture/ich/index.php?lg=en\&pg=00006.

\section{NOTES}

1. The term "Alevi-Bektaşi" is not my own, but is one that is used in the above-cited UNESCO nomination file to denominate the community of various Alevi and Bektaşi organizations involved in the process of heritage construction. The different historical and social trajectories of these groups are discussed in part three of this paper.

2. The cem ritual is a congregational ritual among Alevis. The sequence semah is one of various different parts which constitute the ritual. For an overview on Alevi rituals see Langer 2008, for an idealtypical description of the cem see Karolewski (2005). 
3. The cemevi is the place where the cem ritual takes place. Although possibly any profane place may be rendered into a cemevi, Alevi organizations tend to provide central places for gathering. However, these buildings are not subject to statefunding, which renders their status unequal compared to sunni muslim mosques.

4. For an overview of Alevi ritual practice, see for example Langer (2008). The (ongoing) resentment against Alevi ritual practice is analyzed in its historical context by Karolewski (2008). 5. For a description of the various sequences of the cem ritual see Langer (2008).

6. Coombe mentions the example of ascribing Capoeira mestres outside Brazil with the title of ambassadors of Brazilian Cultural Heritage, which considers actors outside the nation-state of origin as bearers and representatives of their Cultural Heritage (Coombe 2012: 384).

7. Personal note from Interview with an AABF representative held on 17 December 2013 in Hamburg.

8. Berber, Mehmet Ali: "Cemevleri için tekke ve zaviye yasası değişiyor", Sabah Gazetesi, 01. 07. 2013.

9. However, the favourable ruling in the case of Hasan and Eylem Zengin is not universally applicable. Every Alevi pupil seeking to be exempt from class has to present a judgment in their own name from a Turkish court to the Ministry of Education, despite the ruling by the European Court of Human Rights that the exemption procedure was ineffectual for the respect of religious minority rights.

10. These include: Alevi-Bektaşi Federasyonu; Hacı Bektaş Veli Anadolu Kültür Vakfı Genel Merkezi;, Hacı Bektaş Veli Kültür ve Tanıtma Dernekleri Genel Merkezi; Pir Sultan Abdal Kültür Derneği Genel Merkezi; Pir Sultan Abdal 2 Temmuz Kültür ve Eğitim Vakfı, Karacaahmet Sultan Eğitim ve Kültür Vakfi; CEM Vakfı Genel Merkezi; Dünya Ehl-I Beyt Vakfi; Ankara Cem Kültür Evlerini Yaptırma Derneği; Hüseyingazi Derneği; Hubyar Sultan Alevi Kültür Derneği; Hacı Bektaş Derneği; İstanbul Alevi Kültür Derneği; Tahtacı Kültür Eğitim Kalkınma ve Yardımlaşma Derneği; Turhal Kültür ve Dayanışma Derneği; Gazi Üniversitesi Türk Kültürü ve Hacı Bektaş Veli Araştırma Merkezi; and the Alevilik Araştırma Dokümentasyon ve Uygulama Enstitüsü (UNESCO nomination file: 14 ).

11. According to Dressler the term 'Alevi' has a rather young origin, its emergence dating back in its narrower sense - to the $19^{\text {th }}$ and early $20^{\text {th }}$ century (Dressler 2013b: 70). It has often been claimed that 'Kızılbaş' was the historical term for 'Alevi' (see Karakaya-Stump 2013: 279). Although not an entirely incorrect assertion, such a narrative suggests that all present day Alevis are the descendants of the Kizılbaş. It thus fails to grasp either the complex semantic layers of the historical usage of the term 'Alevi' as "(any) follower of Ali" or the various anachronistic projections of a longue durée Alevi identity in Anatolia..

12. The term ocak - "hearth" in the Alevi context refers to the holy family lineages.

13. For example, the Alevi-Bektaşi Federasyonu is rather critical about the AKP's policies towards Alevis (Soner and Toktaş 2011: 424).

14. Interview conducted on 17 December in Hamburg with the aforementioned AABF representative.

15. Personal note from an interview held on 17 December in Hamburg.

16. Additionally, the Turkish term for minority, azınlk, bears a rather negative connotation as Alevis would rather regard themselves as constitutive part of the (original idea) of the Republic (Dressler 2014: 144f.) 


\title{
ABSTRACTS
}

The accelerating references to Cultural Heritage in politics and scholarship have impacted on 'vernacular' or migrant communities' aspirations for the recognition of their distinct identities and have likewise influenced nation-states' policies on cultural diversity. Thus Alevi communities in Turkey and Germany have used the institutions and language provided by intergovernmental actors to claim recognition of their Intangible Cultural Heritage. In 2010, the Alevi-Bektaşi ritual dance, semah, was inscribed onto Turkey's National Inventory for Intangible Cultural Heritage. However, Alevis in Germany, also drawing on the semah as their "useable past", recently initiated their own heritage project. This paper analyses the various functions and uses of heritage discourse in the context of its exercise by both state and non-state actors in Germany and Turkey. It will be argued that a critical investigation must question the empowering and disciplining aspects of the governmentalities of Cultural Heritage because, as demonstrated by the Turkish case, recognition of (Alevi) heritage does not necessarily translate into legal recognition.

\section{INDEX}

Keywords: Alevis, ritual, diaspora, transnational migration, governmentality.

\author{
AUTHOR \\ BENJAMIN WEINECK \\ University of Bayreuth \\ Religionswissenschaft \\ benjamin.weineck@uni-bayreuth.de \\ $\&$ \\ University of Heidelberg \\ Seminar für Sprachen und Kulturen des Vorderen Orients \\ Islamwissenschaft \\ benjamin.weineck@ori.uni-heidelberg.de
}

